\title{
Thomas Hardy: A Better Understanding of his Claimed Pessimism, its Causes and Influence
}

\author{
Dr Mahmoud Nayef Baroud* \\ Assistant Professor of English and Comparative Literature in the English Department at The Islamic University \\ of Gaza, Palestine
}

*Corresponding Author: Dr Mahmoud Nayef Baroud, Assistant Professor of English and Comparative Literature in the English Department at The Islamic University of Gaza, Palestine

\begin{abstract}
It is always interesting and challenging to examine the shaping influences of an artist's mind and writings. Thomas Hardy is no exception. He offers an exceptionally intriguing case where his novels have what can be called a significant element of thought. Critics and readers today, without any apparent sense of incongruity, frequently refer to Hardy as a pessimist novelist but without examining the real causes and impact of such a vision. He is accused of thrusting abstraction and theories on his artistic creation. Exploring his Wessex novels, we need to highlight a major issue which is either his pessimism or realism. An in-depth study of his novels will obviously persuade us that his attitude towards life is pessimistic. In discussing the causes of his pessimism I have chosen to focus on the environment he was living in and how he was influenced by his own Victorian society. As a result of such an age, there is a pessimistic, dismal and fatalistic tone in his novels. This paper is an attempt to discuss Hardy's pessimism with the ultimate goal of finding a better understanding of his pessimistic vision.
\end{abstract}

Keywords: Hardy, Pessimism, Cause, Understanding, Victorian, Novels, Critics, Readers, Characters, Tess..

In this article the reader may encounter an understanding of Thomas Hardy diverse from that in any of the previous studies. By 1922, near the end of his life, Hardy had given up writing fiction hoping that literary critics would understand him. He had stopped writing novels due to the aggressive attacks on his last novel Jude the Obscure where at that time critics approached his work with an ignorant prejudice against his pessimism which they permitted to stand in the way of true reading and impartial judgment. One would argue that he may have felt like this as many modern critics and readers had failed to understand the point of his great novels. The Victorians wanted him to continue writing novels like his Far from the Madding Crowd, which might be called a romantic picture of rural life. They continually abused his best and most serious novel Jude the Obscure because they would have preferred to reduce him to a mass entertainer, supporting their own traditional and mistaken views of what the English countryside was like. In this regard, Merryn Williams thinks that even twentieth century criticism has not got far enough beyond this; 'Hardy's greatness, and his central significance in the history of the English novel, is not understood even today'. (Williams, 1977, p. xi) Obviously she is not considering only T. S. Eliot's cruel attack on him, or DrLeavis's exclusion of his work from the great tradition, for even the rising number of scholars and critics who appreciate Hardy generally fail to understand the idea/point he is writing about. Thus, it is the aim of this paper to provide a better critical understanding and appreciation for Hardy's pessimism, its main cause and subsequent influence on some of his great novels in particular.

In general, it is taken for granted that Hardy was a pessimist, just it was in his lifetime. Hardy was the portraitist of gloomier side of life as it was no strange if some people charged him with pessimism during his lifetime and after his death. This belief seems to be true in this context. In fact, there are some factors that force us to describe him as a pessimist. He was hypersensitive; his own life was tragic and miserable. Watching a bird shivering in the cold would break and hurt his heart. For a speculative soul, his Victorian age is a complicated and controversial field. The most difficult age to write about. The gloomy outcomes of his age have a significant negative impact on his philosophy and the shaping of his writings. Uncertainties, despair, disbelief, frustration, industrial revolution, collapse of old social and economic system and Darwin's theory of evolution were the dominant 
features of that age. All these factors have strongly influenced his writings and intensified its somber, melancholic and tragic vision. His pessimism is also the outcome of the impressions that he receives from villager's life. There were plenty of tragedies in the life of the poverty stricken Wessex folk. In August 1856 he saw the execution of Martha Brown for the murder of her husband, but it was another hanging that left a very vivid memory. Rushing out with a telescope to a higher part of the heath when he suddenly remembered that a hanging was due, Hardy on putting his eye to the telescope saw the white figure of the murderer drop. He had an uneasy sensation that he was alone on the heath with the murderer. That's why Hardy, practically, eliminates from his writings the sense of pleasure and beauty of human life completely. The heroine's life (Tess) in his Tess of the D'Urbervilles is totally devoid of even a temporary single moment of happiness or joy. Due to her immense suffering, she believes that best of all is not to be born at all.

Hardy's conception of life is basically tragic. He is one of those who believe that life is full of hurdles which we cannot override. His novels concentrate on human sufferings and show that there is no escape for human beings. Pessimism runs like a dark thread through his novels. For the sake of the ordinary reader, we may elaborate here with some more details about Tess' suffering in particular. Tess is worst destined to the sufferings of life. She tries her best to come out of her fated sphere of calamities but in vain and remains fail. Throughout the novel she keeps on revolving around the predetermined circles of her fate and the arbitrary social law. Being the eldest child she has to go to her relatives the D'Urbervilles for earning. Her rape/seduction by Alec the womanizer plays a crucial role in her future tragedy. She is rejected by society on becoming pregnant. She goes to earn for her family to Talbothays. Her love affair, her marriage and then sudden denial by Angle Clare because of her past, all this make her a victim of conventional social codes. Once victim, always victim, that's the law. Hardy wrote 'To her and her like, birth itself was an ordeal of degrading personal compulsion, who gratuitousness nothing in the result seemed to justify, and at best could only palliate.' (Tess, 441)Her sufferings in winter season of Talbothays after the departure of her lover and husband Angel Clare and in the wooing with Alec are inexpressible. Her revenge from Alec in order to rejoin Angel and her hanging soon afterwards also show a long series of sufferings that she encounters with a broken but a brave heart. All this shows that Hardy's attitude towards life is unnecessarily melancholic and depressive. He loves people but he hates life intensely. He perceives it in the hands of cruel, blind and oppressive 'Unknown Will'.

Indeed, when prejudices are set aside and the fear of being thought too orthodox or too commonplace disregarded, and when one sits back and scrutinizes with the eye of the common man the fourteen great novels, the short stories, the half-a-dozen volumes of verse (more than eight hundred poems) and the mighty achievement of The Dynasts, what other impression is left than one not only of sadness, but of that hopeless and bleak sadness which pessimism stimulates. Most modern readers of Hardy are strongly persuaded that he was a pessimist. To emphasize their conviction they may find clear evidences in most of his tragic novels. For example, when Elizabeth Jane, of The Mayer of Casterbridge, finds happiness at last she wonders at it, her youth having taught her that happiness was but the occasional episode in a general drama of pain. When Tess of the D'Urbervilles the victim is hanged, Hardy told us in a very ironic way that 'justice was done and the President of Immortals, in Aeschylean phrase, had ended his sport with Tess'.(Tess, 1982, 489)Sadly enough, there is the miserable, sordid and sad tale of the boy Jude in Jude the Obscure, who kills himself and Sue's children because they are 'too many'. According to Hardy, this child Little Father Time is the embodiment of the coming universal wish not to live. Other passages, though less striking are perhaps even better evidence because less directly required by the narrative itself. Somebody might have come along to help Jude in his bewilderment, but nobody did come, because nobody does. One might be surprised from the philosophical or metaphysical remark delivered by Tess when telling her little brothers and sisters that the reason why things are so bad here is that that they live on a blighted star adding 'I sometimes wish I had never been born!'(Tess,255) All these creations of Hardy's leave in the mind, beyond a shadow of doubt, an immense sense of life's saduselessness. Such textual illustrations from his novels would invite us to say that there is no doubt that Hardy's vision is bleak, somber and pessimistic.

Turning to the underlying philosophy of this sadness, we must make the preliminary and obvious concession that in every form of literature it remains to some extent a matter of discussion how much of its philosophy is genuine self-expression, how much artistic device. Here Hardy has himself warned us frequently, as in the often-quoted words of the preface to Tess: 'Let me repeat that a novel 
is an impression, not an argument.'(Tess, 38)But instead of picturing his pessimism as a particular feature of his character, we do need to relate it to the great changes which were taking place and transforming the English countryside society during his age. Douglas Brown calls this 'the contemporary agricultural tragedy' (Brown, 1961, 89) and other critics betray a romantic outlook of the old rustic England which is likewise distorting. One of Hardy's significant topics was the sad passing of the stable rural life, the decay of old customs and of local traditions. The central theme of Hardy's novels is the tension between the old rural world and the new urban one. According to Arnold Kettle, the subject of Hardy's Tess is the destruction of the peasantry, and that Hardy is writing with the pessimism of the Wessex laborer who sees his world and his values being shattered. (Kettle, 2016) Here, we can regard Brown and Kettle as the best of Hardy's critics simply because they relate him to the society he lived in and the circumstances he witnessed instead of perceiving him in isolation as other critics do.

We should remember that the Victorians had other problems than the conflict between the new science and the old religion, problems arising from the clash between Capital and Labour, the development of capitalism and of challenging imperialisms leading up to the World Wars I and II. Such vexing matters would definitely cast their dark shadows on ones' hopes, vision, fears and belief. One, like G. W. Sherman, may make a solid little syllogism of Hardy's pessimism from his novel The Return of the Native and his poems 'Haps' and 'The Convergence of the Twain' - about the destined and tragic meeting between the Iceberg and the great ship Titanic across the Atlantic ocean-but it can hardly be passed off as understanding Hardy. (Sherman, 1976) In order to understand Hardy, we must see him in his age, as Arnold Kettle has observed of Shakespeare. This leads us to assume that Hardy's critics have failed to see him in his Victorian age. This assumption can be applied on the belletrists, the regionalists, the philosophical critics, the Marxists to a lesser degree, and finally the new critics. The second and third were concerned with the question as whether his pessimism was native from Wessex or imported from the German philosophers. The Marxists have either regretted with Granville Hicks that so little was known about Hardy's childhood years in London or considered him as one who sustained England's long middle-class summer. New critics like Albert Guerard proclaim that the facts of Hardy's life are peripheral and need not be examined to an understanding of his novels.

I would in this regard claim that most of Hardy's critics altogether agree on the assumption that he was a pessimist but they have a great deal of disparity on the question related to the cause of his pessimism. Is it due to his influence by his earlier readings of Darwin, Spencer, Huxley and Mill or part of his personality? According to critics like Sherman, most critics have finally agreed that it was the influence of Darwin's influential book Origin of Species (1859) which at that time created a conflict between scientists and the church which in turn led to a state of confusion, doubt and skepticism among individuals including authors and philosophers. Of course, this should not be taken for granted and it needs some sort of debate as we shall see below. In 1921 Hardy remarked to Vere Collins, 'Why are people always talking about pessimism, I suppose pessimism is an easy word to say and remember. It's only a passing fashion.' (See Collins, 1978, 63)Moreover, he has ironically observed that taking a melancholy or gloomy view of life was the certain way of defending oneself against the many frustrations and depressions in life. Actually much of his gloom and displeasure arose from the injustice of a mercantilist society and the exploitation of the needy and the poor by the rich, particularly at the expense of farmworkers or workfolk. It is simply from man's inhumanity to man. In his Wessex novels (such as The Return of the Native and Tess of the D'Urbervilles), Hardy did protest long before Conrad did in his essay 'Autocracy and War' (1905) against Commercialism and Industrialism in which Western nations had put their faith. Hardy criticized the proponents of 'Progress, Expansion, and Prosperity'- those optimists who were saying 'All is well when all is not well,' who blind the eyes on the real malady and use empirical panaceas to suppress the symptoms, declaring that 'if a way to the Better there be, it exacts a full look at the Worst,' as he wrote in 1898. (Florence Hardy, 1928, 183) Throughout his relatively long life Hardy witnessed and embraced a record of depressive cycles and colonizing wars and competitions leading up to World War One, which had its negative ramifications on life aspects and sadly destroyed one's hope for mankind and humanity at large. The implied remark we need to articulate and stress is the fact that the genuine cause of his pessimism was not simply his loss of faith in God from having reading Darwin's Origin of Species as a young novelist, but his loss of faith in the political leaders of his Victorian society, both Conservative and Labor alike. 
As one can observe in most of his novels, Hardy's sympathy was always with the individuals from the working classes against the rigid conventions of his society and the church corruption. Most of the best and well known characters in his novels meet unpleasant ends - largely because they are unable to break out of social conventions, financial woe or other difficulties. This is clear in his choice of his ordinary heroes and heroines for his novels: Gabriel Oak in Far from the Madding Crowd, Clym Yeobright in The Return of the Native, Giles Winterborne and Marty South in The Woodlanders, Michael Henchard in The Mayer of Casterbridge, the pure lady and dairymaid Tess and finally Jude the Obscure, the poor student and stones man who, deprived of an education, discovers that something is basically wrong with society and beyond the individual's power to change it. In addition, Hardy depicts the mentioned characters as having fared better in their simple clothes under the Household system than in the cottons and worsteds of their new industrial masters for whom the mildly liberal M. $\mathrm{P}$ shed tears over the blessings of free-trade and the profits of the eminent men of Bradford who deal in worsteds. Comparatively speaking, it is clear that Hardy did not decide to write on the Industrial working classes as did George Gissing in England and Maxim Gorki in Russia, because he did not know them as they did. Hardy's working people are country farmers, agricultural laborers where the impact of the Industrial Revolution is evident on their lives throughout the introduction of the corndrill (The Mayer) and the invention of the steam-thresher (Tess). Here, we can mention the effect of the steam-engine on the emigration of the workfolk to the larger towns, comparing it to water being forced uphill by the pressure of machinery. Expelled and dispossessed from their own land and homes, they could not find employment in the larger towns and they had no fortune either in hardship or prosperity and no voice in government under either Whig or Tory rule.

Hardy himself was sadly offended by what he considered as invalid charges. He sought to justify his view of life on many occasions and in various ways. In defense of himself and in a conversation with William Archer in 1904 (quoted in A Hardy Companion by F. B. Pinion) he said '...I believe, indeed, that a good deal of the robustious, swaggering optimism, of recent literature is at bottom cowardly and insincere...my pessimism, if pessimism it be, does not involve the assumption that the world is going to the dogs... On the contrary, my practical philosophy is distinctly meliorist... What are my books but one long plea against man's inhumanity against man - to women - and to the lower animals?' (Mathur, 1982, 23) Hardy attempted a justification of his dark outlook when he declared that 'the highest flights of the pen are mostly the excursions and revelations of souls unreconciled to life. Consequently he regarded himself as a 'meliorist' rather than a 'pessimist.'

Of course it would be inconvenient to request from every writer that he/she should be the conveyer of some message of hope to his readers. That would be but a risky form of the conviction or rather the prejudice that, all great writing must be moralistic or educational. But the unlucky fact remains that all writing, whether great or small, is as a matter of fact didactic in the plain sense that it puts into the head of the reader whom it captivates ideas on which he is likely to act.And when the writing in question hovers about so dark and troubling a theme as that of the concept of evil, the risk is all the greater.

Hardy is not a pessimist - a misanthrope (somebody who hates humanity) like Hobbes. He is a pessimist like the classical writers who view Man simply as a puppet in the hands of powerful fate as can be seen in Greek tragedies. Simply he is gloomier than they are. Instead of causing in the reader a feeling of disgust and scorn for the shortcomings of his characters, hecreates in them a feeling of deep sympathy. This is due to his profound sympathy for humanity.

Equally important, since he was describing life as it really was why don't we also elaborate and suggest that his pessimism is mixed up with some sort of realism as well. One note which Hardy strikes repeatedly is his insistence on realism; his whole aim seems to have been to present the Truth regardless of the consequences.

\section{REFERENCES}

[1] Williams, Merryn. Thomas Hardy and Rural England. London and Birmingham: The Macmillan Press LTD., 1977.

[2] Brown,Douglas. Thomas Hardy, London: 1961.

[3] Kettle, Arnold. AnIntroduction to English Novel.London: Routledge, 2016.

[4] Sherman, G. W. The Pessimism of Thomas Hardy: A Social Study. FairleighDickinson University Press,U.S. 1981. 
[5] Collins, Vere. Talks with Thomas Hardy at Max Gate.London: Norwood Editions, 1978.

[6] Hardy, Florence E. The Later Years of ThomasHardy.New York: Macmillan, 1930.

[7] Hardy, Thomas. Tess of the D'Urbervilles.Edited by David Skilton.USA: Penguin English Library, 1982.

[8] Hardy, Thomas. Jude the Obscure.London: Wordsworth Editions, 2000.

[9] Pinion, F. B.A Hardy Companion: A Guide to the Works of Thomas Hardy. London: Macmillan, 1974.

[10] Mathur, U. S. ThomasHard: Tess of the d'Urbervilles. New Delhi: Aarti Book Centre, 1982.

\section{AUTHOR'S BIOGRAPHY}

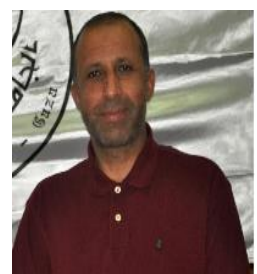

Mahmoud Nayef Baroud is Assistant Professor of English and Comparative Literature in the English Department at The Islamic University of Gaza, Palestine. He holds a Ph.D. in Comparative Literature from the University of Exeter, UK. He is the author of The Shipwrecked Sailor in Arabic and Western Literature published by I. B. Tauris in London. He is the current Head of the IFP Gaza Alumni Association.

Citation: Dr Mahmoud Nayef Baroud. "Thomas Hardy: A Better Understanding of his Claimed Pessimism, its Causes and Influence" International Journal on Studies in English Language and Literature (IJSELL), vol 6, no. 7, 2018, pp. 1-5. doi:http://dx.doi.org/10.20431/2347-3134.0607001.

Copyright: (C) 2018 Authors. This is an open-access article distributed under the terms of the Creative Commons Attribution License, which permits unrestricted use, distribution, and reproduction in any medium, provided the original author and source are credited. 